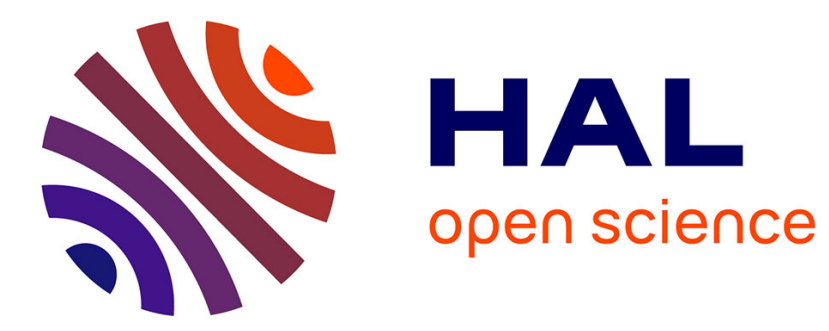

\title{
In vitro bio-functional performances of the novel superelastic beta-type Ti-23Nb-0.7Ta-2Zr-0.5N alloy
}

Raluca Ion, D.-M. Gordin, Valentina Mitran, Petre Osiceanu, Sorina Dinescu, Thierry Gloriant, A. Cimpean

\section{To cite this version:}

Raluca Ion, D.-M. Gordin, Valentina Mitran, Petre Osiceanu, Sorina Dinescu, et al.. In vitro biofunctional performances of the novel superelastic beta-type Ti-23Nb-0.7Ta-2Zr-0.5N alloy. Materials Science and Engineering: C, 2014, 35, pp.411-419. 10.1016/j.msec.2013.11.018 . hal-00919011

\section{HAL Id: hal-00919011 \\ https://hal.science/hal-00919011}

Submitted on 16 Dec 2013

HAL is a multi-disciplinary open access archive for the deposit and dissemination of scientific research documents, whether they are published or not. The documents may come from teaching and research institutions in France or abroad, or from public or private research centers.
L'archive ouverte pluridisciplinaire HAL, est destinée au dépôt et à la diffusion de documents scientifiques de niveau recherche, publiés ou non, émanant des établissements d'enseignement et de recherche français ou étrangers, des laboratoires publics ou privés. 


\title{
In vitro bio-functional performances of
}

\section{the novel superelastic beta-type Ti-23 Nb-0.7Ta-2Zr-0.5N alloy}

\author{
Raluca Ion ${ }^{\mathrm{a}}$, Doina-Margareta Gordin ${ }^{\mathrm{b}}$, Valentina Mitran ${ }^{\mathrm{a}}$, Petre Osiceanu ${ }^{\mathrm{c}}$, \\ Sorina Dinescu ${ }^{\mathrm{a}}$, Thierry Gloriant $^{\mathrm{b}}$, Anisoara Cimpean $^{\mathrm{a}^{*}}$
}

${ }^{a}$ University of Bucharest, Department of Biochemistry and Molecular Biology, 91-95 Spl. Independentei, 050095, Bucharest, Romania

${ }^{b}$ INSA Rennes, UMR CNRS 6226 SCR/Chimie-Métallurgie, 20 avenue des Buttes de Coësmes, F-35043 Rennes Cedex, France

'Institute of Physical Chemistry "Ilie Murgulescu”, 202 Spl. Independentei, 060021, Bucharest, Romania

${ }^{*}$ Corresponding author:

E-mail address: anisoara.cimpean@bio.unibuc.ro

Tel.: +40 21 3181575/106; Fax: +40 $213181575 / 101,102$

University of Bucharest, Department of Biochemistry and Molecular Biology, 91-95 Spl. Independentei, 050095, Bucharest, Romania 
ABSTRACT: The materials used for internal fracture fixations and joint replacements are mainly made of metals which still face problems ranging from higher rigidity than that of natural bone to leaching cytotoxic metallic ions. Beta $(\beta)$-type titanium alloys with low elastic modulus made from non-toxic and non-allergenic elements are desirable to reduce stress shielding effect and enhance bone remodeling. In this work, a new $\beta$-type Ti-23Nb-0.7Ta$2 \mathrm{Zr}-0.5 \mathrm{~N}$ alloy with a Young's modulus of approximately $50 \mathrm{GPa}$ was designed and characterized. The behavior of MC3T3-E1 pre-osteoblasts on the new alloy, including adhesion, proliferation and differentiation, was evaluated by examining the cytoskeleton, focal adhesion formation, metabolic activity and extracellular matrix mineralization. Results indicated that the pre-osteoblast cells exhibited a similar degree of attachment and growth on Ti-23Nb-0.7Ta-2Zr-0.5N and Ti-6Al-4V. However, the novel alloy proved to be significantly more efficient in sustaining mineralized matrix deposition upon osteogenic induction of the cells than Ti-6Al-4V control. Further, analysis of RAW 264.7 macrophages cytokine gene and protein expression indicated no significant inflammatory response. Collectively, these findings suggest that the Ti-23Nb-0.7Ta-2Zr-0.5N alloy, which has an increased mechanical biocompatibility with bone, allows a better osteogenic differentiation of osteoblast precursor cells than Ti-6Al-4V and holds great potential for future clinical prosthetic applications.

Keywords: beta-titanium alloy; osteoblast; differentiation; macrophage; inflammatory response. 


\section{Introduction}

Titanium (Ti) alloys are well established materials of choice for medical applications such as joint replacements, bone screws and plates, dental implants and surgical components due to their good mechanical properties and biocompatibility [1]. However, Young's moduli of the widely used Ti-based implant devices are generally higher than that of human bone which affects long-term practical performances due to the stress shielding phenomenon [2]. The effects associated with stress shielding at the level of bone-implant system create multiple undesired phenomena and may finally lead to contact loosening, premature implant failure or debris-induced infections [3]. This explains why in the design of Ti alloys for biomedical applications, the reduction of the elastic stiffness must be regarded as a high priority constraint in the overall strategy. Studies conducted in vivo have proved that Ti-based alloys with low Young's modulus are effective for inhibiting bone atrophy and enhancing bone formation [4-6]. Also, there is much effort currently dedicated to replace with safer alloying elements aluminium and vanadium from commercial $\mathrm{Ti}$ bioalloys due to their cytotoxicity $[7,8]$, providing better mechanical properties, reducing elastic modulus closer to that of the human bone, while retaining high strength in the new alloys. Consequently, a new generation of low modulus $\beta$-Ti alloys, which are free of vanadium and aluminium is being developed with $\beta$-stabilizing and biocompatible elements such as $\mathrm{Nb}$, Ta and $\mathrm{Zr}$ [9-19].

On the other hand, it was reported in literature that in a given composition domain, the quenched $\beta$ microstructure is decomposed into a stress-induced alpha" martensite when an external stress is applied. This phenomenon is generally highlighted by a characteristic tensile stress-strain curve showing a nonlinear elastic domain and a stress plateau associated with a double yielding behavior. As the stress-induced martensitic transformation is reversible, a high recoverable strain can be obtained, leading to a superelastic effect [20-22]. The super- 
elastic behavior of these materials may provide benefits especially for joint replacements who are subjected to cyclical stresses during daily activities. Moreover, the super-elastic effect could be used to help anchor the implant within the receiving bone cavity. To our knowledge, there has been only one study reporting on the in vivo super-elastic biomechanics and corresponding osteointegration effects. Liu et al. [23] compared the performance of porous nitinol with that of porous titanium, dense nitinol and dense titanium. They found that porous nitinol fosters fast bone ingrowth and osteointegration, and the bonding strength is enhanced significantly compared to other metallic implants including porous titanium, characterized by a lower Young's modulus and a bioactive surface layer, which does not possess superelasticity. This superelastic effect is accompanied by a very significant reduction of the elastic modulus, which is highly beneficial for the use of these alloys like prostheses or implants in osseous sites. On the other hand, these non-allergen Ni-free alloys can be envisaged to replace the superelastic NiTi-based materials currently used for the fabrication of functional biomedical dispositives such as cardiovascular stents or orthopedic staples, for example.

In this context, the aim of the present study was to assess the cellular response to the newly developed low modulus superelastic $\beta$-type Ti-23Nb-0.7Ta-2Zr-0.5N alloy composition. Two different cell types were used: MC3T3-E1 pre-osteoblasts and RAW 264.7 macrophages. The latter cell type was used to determine potential inflammatory responses to the materials by measuring release of the pro-inflammatory cytokines and chemokines such as tumor necrosis factor (TNF)- $\alpha$, interleukin (IL)-6, monocyte chemotactic protein (MCP)-1 and regulated upon activation normal $\mathrm{T}$ cell expressed and secreted (RANTES). Gene expression analysis of these molecules has also been performed. For comparative purposes, Ti-6Al-4V was used as a control. Osteoblasts response to $23 \mathrm{Nb}-0.7 \mathrm{Ta}-2 \mathrm{Zr}-0.5 \mathrm{~N}$ alloy was evaluated in terms of cell attachment and spreading, cell morphology, cell proliferation, and 
matrix mineralization in order to prove its suitability as bone implant material. Also, the microstructure, composition and the mechanical properties investigated by tensile tests of the Ti-23Nb-0.7Ta-2Zr-0.5N alloy are presented and discussed. 


\section{Materials and methods}

\subsection{Alloy synthesis and characterization}

The Ti-23Nb-0.7Ta-2Zr-0.5N alloy (chemical composition given in at. \% with the balance Ti) was synthesized by cold crucible levitation melting technique (CCLM) under high vacuum. Ingots obtained from melting were next homogenized at $1223 \mathrm{~K}$ for $72 \times 10^{3} \mathrm{~s}$ under high vacuum, followed by water quenching. Ingots were then cold rolled at room temperature until a $90 \%$ of reduction in thickness was achieved. From this cold-rolled state, samples were cut in disc shape pieces for the biological tests or machined into flat tensile specimens for the tensile tests. Finally, all samples were solution-treated in the $\beta$-phase domain at $1123 \mathrm{~K}$ for $1.8 \times 10^{3} \mathrm{~s}$ under vacuum in order to restore a fully recrystallized microstructure and water quenched to retain the metastable beta microstructure at room temperature.

For the biological tests, disc-shaped samples, with a disc diameter of $13 \mathrm{~mm}$ and a thickness of $1 \mathrm{~mm}$, were mechanically polished on silicon carbide abrasive papers (up to 4000 grit) and then ultrasonically cleaned in acetone, thoroughly washed with ethanol and dried in air. For comparison, the commercially Ti-6Al-4V alloy (Goodfellow supplier) was chosen as reference and samples from this alloy were prepared similarly.

Roughness of the samples used for the biological tests were evaluated by atomic force microscopy (AFM, CSM Instruments). For that, tapping mode was used in air with a silicon tip. To evaluate the roughness, 12 measurements were obtained from 83 × $83 \mu \mathrm{m}$ AFM scans taken from each sample surface.

The measurements of water contact angle, which plays an important role in determining the dynamics of protein-surface interaction, surface fouling and cell-substrate responses [24], 
were performed according to ASTM D7334 - 08 [25] using Contact Angle Meter KSV Instruments CAM 100. Each contact angle value is the average of minimum 10 frames with the frame interval up to $100 \mathrm{~ms}$; the drop volume was $3 \mu \mathrm{L}$. The investigation was carried out with an accuracy of $\pm 1^{\circ}$ at a temperature of $25^{\circ} \mathrm{C}$.

The Ti-23Nb-0.7Ta-2Zr- $0.5 \mathrm{~N}$ alloy microstructure was observed by optical microscopy (LEICA DM/RM). To be observed, the sample was polished to a final "mirror" polishing state using a colloidal silica suspension (particles size: $50 \mathrm{~nm}$ ) and was etched in an acid solution containing $5 \% \mathrm{HNO}_{3}, 5 \% \mathrm{HF}$ and $90 \% \mathrm{H}_{2} \mathrm{O}$ to reveal the microstructure.

Surface analysis performed by X-Ray Photoelectron Spectroscopy (XPS) was carried out on a Quantera SXM equipment, with a base pressure in the analysis chamber of $10^{-9}$ Torr. The X-ray source was $\mathrm{Al} \mathrm{K}_{\alpha}$ radiation $(1486.6 \mathrm{eV}$, monochromatized) and the overall energy resolution was estimated at $0.6 \mathrm{eV}$ by the full width at half maximum (FWHM) of the $\mathrm{Au} 4 \mathrm{f}_{7 / 2}$ line. In order to take into account the charging effect on the measured Binding Energies (BEs), the spectra were calibrated using the $\mathrm{C} 1 \mathrm{~s}$ line $(\mathrm{BE}=284.8 \mathrm{eV}, \mathrm{C}-\mathrm{C}(\mathrm{CH}) \mathrm{n}$ bondings) of the adsorbed hydrocarbon on the sample surface. A dual beam (electrons and $\mathrm{Ar}^{+}$) was used for a complete neutralization of the surface.

Tensile tests until rupture were carried out using an INSTRON 3369 machine with a strain rate of $10^{-4} \mathrm{~s}^{-1}$. An extensometer was used to precisely measure the deformation of the specimens. In addition, the superelastic behavior of the alloy was characterized from cyclic tensile tests with strain increments of $0.5 \%$ followed by stress release up to an elongation of 4\% (loading-unloading cycles). Tensile specimens were machined to obtain normalized shapes: $3 \mathrm{~mm}$ width, $0.5 \mathrm{~mm}$ in thickness and a gage length of $15 \mathrm{~mm}$.

\subsection{Cell cutures}


Mouse pre-osteoblast MC3T3-E1 (American Type Culture Collection) and mouse macrophage RAW 264.7 (American Type Culture Collection) cell lines were cultured in Dulbecco's Minimal Essential Medium supplemented with 10\% (v/v) foetal bovine serum and $1 \%(\mathrm{v} / \mathrm{v})$ penicillin/streptomycin $(10,000$ units $/ \mathrm{mL}$ penicillin and $10 \mathrm{mg} / \mathrm{mL}$ streptomycin). Both cell lines were incubated at $37{ }^{\circ} \mathrm{C}$ in a humidified atmosphere of $5 \% \mathrm{CO}_{2}$ for specific times. Pre-osteoblastic MC3T3-E1 cells were seeded onto metallic specimens placed in 12-well cell culture plates at a density of $10^{4}$ cells $/ \mathrm{cm}^{2}$ for cell attachment and spreading, cell morphology and cell proliferation studies, while macrophage-like RAW 264.7 cells were plated on test alloys at a density of $2.5 \times 10^{4}$ cells $/ \mathrm{cm}^{2}$ in two different conditions: non-inflammatory and pro-inflammatory using $10 \mathrm{ng} / \mathrm{ml}$ of Escherichia coli lipopolysaccharide (LPS). All cell culture-based assays were conducted in triplicate for each sample.

\subsection{Fluorescence labeling of actin and vinculin}

After $3 \mathrm{~h}$ and $24 \mathrm{~h}$ of culture, the osteoblasts grown on Ti alloys were fixed with $4 \%$ paraformaldehyde prepared in phosphate buffered saline (PBS), permeabilized and blocked with $0.1 \%$ Triton $\mathrm{X}-100 / 2 \%$ bovine serum albumin for $30 \mathrm{~min}$. and washed with PBS. The samples were then incubated with vinculin antibody (Santa Cruz Biotechnology, dilution 1:50) for $2 \mathrm{~h}$ at room temperature, washed again with PBS and incubated for $1 \mathrm{~h}$ with AlexaFluor488-conjugated specific secondary antibody (Invitrogen, dilution 1:200). Afterwards, phalloidin-TRITC (tetramethylrhodamine B isothiocyanate) $(10 \mu \mathrm{g} / \mathrm{ml}$; SigmaAldrich) was added, and the samples were incubated at room temperature for $15 \mathrm{~min}$. The labelled cells were washed three times with PBS and examined by using Olympus IX71 
microscope equipped for epifluorescence. The images were captured by means of Cell $\mathrm{F}$ image acquiring system.

\subsection{Cell viability and proliferation}

Viability of MC3T3-E1 and RAW 264.7 cells was evaluated after 2, 4, 7 and 1, 2 days of culture, respectively. This study was conducted by MTT colorimetric assay which also provides a useful indication of cell proliferation rates. To perform MTT assay, the solution of 3- (4,5-dimethylthiazol-2-yl)-2,5-diphenyltetrazolium bromide in serum free culture medium $(1 \mathrm{mg} / \mathrm{ml})$ was added into wells being assayed, and the cells were incubated for another $3 \mathrm{~h}$ at $37{ }^{\circ} \mathrm{C}$. Then, the MTT solution was decanted and formazan crystals were solubilized with 1 $\mathrm{ml}$ of dimethyl sulfoxide. Absorbance of dye was measured at a wavelength of $550 \mathrm{~nm}$ and recorded using a microplate reader (Thermo Scientific Appliskan).

\subsection{Pre-osteoblast differentiation on the titanium alloys}

For differentiation assay, pre-osteoblastic cells were seeded onto samples at a density of 5 $\mathrm{x} 10^{4}$ cells $/ \mathrm{cm}^{2} .24 \mathrm{~h}$ post-seeding, differentiation was induced by maintaining the cells in culture media supplemented with $50 \mu \mathrm{g} / \mathrm{ml}$ ascorbic acid (AA) (Sigma-Aldrich) and $5 \mathrm{mM}$ beta-glycerophosphate ( $\beta$-GP) (Sigma-Aldrich). The medium was changed three times per week during the culture period. Cell differentiation was evaluated after 2, 4 and 6 weeks of culture by Alizarin red staining for matrix mineralization. The cell layers were washed twice with PBS, fixed with $10 \%$ formalin solution for $20 \mathrm{~min}$, and then washed with pure water three times. For Alizarin red S staining, the cells were placed in $1 \mathrm{mg} / \mathrm{ml}$ Alizarin red $\mathrm{S}$ (Sigma-Aldrich) solution for $30 \mathrm{~min}$. After stain removal and washing the samples with 
distilled water, gross view photographs were taken using Nikon D3000 digital camera. Then, the cells were air-dried and deposited calcium was quantified by removing the Alizarin stain with $5 \% \mathrm{v} / \mathrm{v}$ perchloric acid for $10 \mathrm{~min}$ and reading the absorbance of the resulting solution at $405 \mathrm{~nm}$.

\subsection{Quantitative Polymerase Chain Reaction ( $q P C R$ )}

Cells were harvested from the samples at $24 \mathrm{~h}$ and $48 \mathrm{~h}$ post-seeding. Total RNA from RAW 264.7 cells was isolated using RNA PureLink Mini Kit (Ambion, Life Technologies, Foster City, CA, USA), according to the manufacturer's protocols and tested for integrity on BioAnalyzer 2100 (Agilent Technologies, Waldbronn, Germany) and purity on NanoDrop spectrophotometer (Shimadzu, Duisburg, Germany). One microgram of total cellular RNA was reverse transcribed to corresponding cDNA using iScript cDNA Synthesis kit (BioRad, Hercules, CA, USA). Sequences of gene-specific primers used in qPCR assay are presented in Table 1 along with the sequences designed for the GAPDH reference gene. The melting temperature optimization for these primers was carried out based on standard PCR components (GoTaq DNA Polymerase kit) provided by Promega, Madison, WI, USA via gradient PCR on a Corbett thermocycler, in $52-62^{\circ} \mathrm{C}$ range of temperatures. The gradient PCR amplicons were subjected to $2 \%$ agarose electrophoresis, followed by ethidium bromide (Roth, Karlsruhe, Germany) staining. The relative gene expressions of IL-6, TNF- $\alpha$, MCP-1 and RANTES markers of the inflammation process were assessed by RealTime RT-PCR on a LightCycler 2.0 carrousel-based system using LightCycler Fast Start DNA Master SYBR Green I Kit (Roche, Mannheim, Germany).

\subsection{Quantification of cytokines and chemokines secreted}


Commercially available enzyme-linked immunosorbent assay (ELISA) kits (R\&D Systems) were used to determine the concentrations of secreted TNF- $\alpha$, IL-6, MCP-1 and RANTES according to package insert instructions. To eliminate variation due to differences in cell viability, concentrations were expressed in relation to the number of control cells, according to MTT results, as follows: normalized $\mathrm{pg} / \mathrm{ml}=$ measured $\mathrm{pg} / \mathrm{ml} \times($ control cells MTT OD/sample cells MTT OD). Secreted cytokine production was measured in supernatants harvested at $24 \mathrm{~h}$ and $48 \mathrm{~h}$ post-seeding.

\subsection{Statistical analysis}

Statistical analysis of the data was performed with GraphPrism software using one-way ANOVA with Bonferroni's multiple comparison tests. All results are expressed as means \pm SD (standard deviation) and $\mathrm{p}$ values of less than 0.05 were considered statistically significant. 


\section{Results and discussion}

A very important criterion for selecting an implantable biomaterial is represented by its biocompatibility. Our studies have investigated pre-osteoblast and macrophage responses to the newly developed superelastic $\beta$-type Ti-23Nb-0.7Ta-2Zr-0.5N alloy.

\subsection{Alloy characterization}

Fig. 1 shows an optical micrograph displaying the typical microstructure of the solutiontreated and quenched Ti-23Nb-0.7Ta-2Zr-0.5N alloy. As it can be observed, the microstructure consists of a fully $\beta$-grain microstructure with a grain dimension varying between a few tens to a few hundreds of micrometers.

XPS analysis in Survey mode was used to determine the chemical elements present on the surface $(<10 \mathrm{~nm})$ and, after quantitative analysis, to determine their relative concentrations, as well. It is appropriate to note here that all the calculations were performed assuming that the sample was homogeneous within the XPS detected volume. We have to emphasize that the errors in our quantitative analysis (relative concentrations) were estimated in the range of $\pm 10 \%$, while the accuracy for Binding Energies (BEs) assignments was $\pm 0.2 \mathrm{eV}$. The spectral signatures (BEs) (Fig. 2 and Table 2) display the presence on the surface of a native oxide layer $(\sim 9.0 \mathrm{~nm}$ in depth) with $\mathrm{Ti}, \mathrm{Zr}$ and $\mathrm{Nb}$ in their full oxidation states, while $\mathrm{Ta}$ exhibits suboxide states (a mixture of $\mathrm{TaO}$ and $\mathrm{Ta}_{2} \mathrm{O}_{3}$ ). The surface stoichiometry calculated by XPS quantification is found in good agreement with the nominal (bulk) stoichiometry. Nevertheless, nitrogen is found in excess leading to the conclusion that during thermal treatment a segregation effect from the bulk to the surface occurs. However, a small contribution from the nitrogen adsorption found in the atmosphere cannot be ruled out. It is 
worth to notice that besides the unavoidable surface contamination with carbon from hydrocarbons and $\mathrm{CO}_{2}$ adsorbed from environment, no other contaminant was found on the surface leading to the conclusion that the surface is stable and clean even in the "as received" state.

In Fig. 3, it is reported a typical stress-strain curve until rupture obtained from the Ti$23 \mathrm{Nb}-0.7 \mathrm{Ta}-2 \mathrm{Zr}-0.5 \mathrm{~N}$ alloy by tensile test. On the other hand, the cyclic tensile curve between 0 and $4 \%$ of strain is also presented in this figure (center part) in order to characterize properly the superelastic behavior of such alloy. It is necessary to note the excellent repeatability of the mechanical experiments because very similar strain-stress tensile curves were obtained for the five tests carried. Only a significant difference concerning the elongation at rupture was observed (around 5\%) due to the fact that the rupture can be strongly influenced by the surface preparation inducing sometime crack ignition sites. It can be clearly observed the nonlinearity of the elastic domain and the presence of hysteresis loops between each loading-unloading cycle, which is characteristic of the superelastic property possessed by such alloy. From this curve an important elastic recovery at about $2.2 \%$ was evaluated and a low incipient Young's modulus measured at 50 GPa was found, which is very low compared to that obtained from classical titanium alloys currently used in medicine (110 GPa for Ti-6Al-4V) and closer to the one that corresponds to the cortical bone (20-30 GPa). These good properties are due to the fact that a stress-induced martensitic transformation occurred in this alloy. As observed in literature [20], this transformation is accompanied by a significant reduction of the Young's modulus and a large elastic recovery due to its reversible character. On the other hand, the tensile curve shows both high yield strength and ultimate tensile strength, which are almost twice higher in comparison with binary the $\mathrm{Ti}-26 \mathrm{Nb}$ alloy reported from literature [21]. This strengthening, is due to the fact that nitrogen, as interstitial element, is well known to involve a solid-solution 
hardening effect in alloys. In addition, it can be noticed that nitrogen addition leads also to a higher superelasticity (almost by 1.5 higher) in comparison with the Ti-Nb, Ti-Nb-Ta or Ti$\mathrm{Nb}-\mathrm{Ta}-\mathrm{Zr}$ superelastic alloys reported from literature $[9,11,13,20-22,24]$. Consequently, this new Ti-23Nb-0.7Ta-2Zr-0.5N alloy, combining high strength, high superelasticity, low modulus and good ductility, is very interesting for a use in medicine.

Examples of AFM maps showing the surface topography of each polished alloy are presented in Fig. 4. From all AFM maps obtained (12 from each alloy composition), the roughness value, Ra, was evaluated to be $98 \pm 7 \mathrm{~nm}$ and $89 \pm 6 \mathrm{~nm}$ for Ti-23Nb-0.7Ta-2Zr$0.5 \mathrm{~N}$ and Ti-6Al-4V, respectively. Thus, very close roughness values in the nanometer range were found on the surface of these two alloys which can minimize any influence of surface topography on cell adhesion and function. Furthermore, water contact angle determination permitted the evaluation of wettability behavior for investigated samples. Both surfaces were found slightly hydrophilic with contact angles of $76.891 \pm 1.201^{\circ}$ and $72.821 \pm 1.129^{\circ}$ for Ti$23 \mathrm{Nb}-0.7 \mathrm{Ta}-2 \mathrm{Zr}-0.5 \mathrm{~N}$ and Ti-6Al-4V, respectively. Therefore, we also can assume that any differences in cellular response between the two alloys are unlikely to be attributed to wettability, which is known to affect the adsorbed protein layer and, consequently, the events at cell-material interface.

\subsection{MC3T3-E1 cell adhesion and morphology}

Cell attachment, adhesion and spreading belong to the first phase of cell/material interactions and depend strongly on the physical and chemical properties of the biomaterial surface [26]. Moreover, the bioactivity and biocompatibility of biomaterials are very closely related to the behavior of cells in contact with them and, particularly, to cell adhesion to their surface [27]. While the attachment phase occurs rapidly and involves physicochemical bonds 
such as ionic and Van der Waals forces between cells and materials, cell adhesion occurs over a longer term and is mediated through focal adhesions, which are large dynamic complexes of organized protein clusters that link the extracellular matrix (ECM) through integrin-ECM binding to the intracellular cytoskeleton [28, 29]. Furthermore, focal adhesions activate signaling pathways which control cell function and architecture [30]. Vinculin is a major protein of focal adhesions and a key player in the regulation of cell adhesion [31]. Therefore, vinculin provides a valuable detection system for focal adhesion sites by means of specific antibody detection.

Cell morphology and adhesion were both investigated in this study to assess the biocompatibility of Ti-23Nb-0.7Ta-2Zr- $0.5 \mathrm{~N}$ substrate compared to Ti-6Al-4V in an in vitro environment. Organization of actin cytoskeleton was visualized by incubation with TRITCconjugated phalloidin, whereas focal adhesion formation was analyzed by immunocytochemistry using a monoclonal antibody against vinculin (Fig. 5).

As shown in Fig. 5, three hours after seeding nearly all the cells, initially round, were spread and displayed cellular extensions in different directions. Over time adherent cells increased in area and gradually elongated. Thus, at $24 \mathrm{~h}$ after plating the cells exhibited a well-defined polygonal or spindle-shaped morphology, typical for osteoblasts. A high degree of cell attachment and spreading was observed on both alloys. Further on, high resolution fluorescence images showed a circumferential localization of actin filaments near the cell membrane at $3 \mathrm{~h}$ post-seeding. Moreover, at this time point, the cytoskeleton began to show a pattern of parallel-orientated actin filaments which later developed into well-defined arrangements of actin stress fibres oriented in a parallel direction following the main cellular axis. No significant differences in the cytoskeletal framework were observed between materials. Furthermore, almost similar patterns of vinculin staining were observed on both alloys. Thus, at $3 \mathrm{~h}$ post-seeding, vinculin staining signals were localized to cytoplasmic 
regions showing predominantly a punctiform pattern which suggests formation of focal contacts between plasma membrane and extracellular proteins adsorbed to both material surfaces. In the MC3T3-E1 cells cultured for $24 \mathrm{~h}$, immunoreactive sites for vinculin were found in the peripheral regions of the cells, predominantly at the termini of actin microfilament bundles resulting in focal adhesion patches, and displaying punctiform pattern at the subcellular level in the plasma membrane near the nucleus area.

Taken together, these data show that cells responded to both materials in an almost identical manner, possibly due to similar topography, roughness and wettability of test materials. Thus, we can draw the conclusion that Ti-23Nb-0.7Ta-2Zr-0.5N alloy is a suitable substrate for cell attachment and adhesion, and allows a normal development of actin cytoskeleton. To the best of our knowledge, the cellular response to superelastic $\beta$-type titanium alloys has not been yet extensively investigated. Such a study has been performed by Arciniegas et al. [32] on the superelastic Ti19.1Nb8.8Zr alloy in comparison with Ti grade II (cpTi) and a $\beta$-type Ti41.2Nb6.1Zr. The in vitro studies were achieved on MG63 osteoblasts and conducted using both indirect and direct contact methods demonstrating that all three samples display a good short-term biological behavior in terms of cell viability and attachment. Noteworthy, the obtained results suggested that although no significant differences in the number of adherent viable osteoblasts were remarked, the speed of cell attachment was higher on the Ti19.1Nb8.8Zr alloy, followed by Ti41.2Nb6.1Zr and cpTi.

\subsection{Pre-osteoblast proliferation}

In order to evaluate if the Ti-23Nb-0.7Ta- $2 \mathrm{Zr}-0.5 \mathrm{~N}$ surface could affect proliferative activity, we monitored cell growth for up to 7 days with MTT assay (Fig. 6). Although the number of viable metabolically active cells was higher on control sample at all studied time 
points, no statistically significant differences in cell proliferation activity between analyzed samples were found out. Moreover, a marked increase in the cell number with culturing time was observed on both alloys confirming their growth-supporting capacity.

\subsection{Matrix mineralization}

An essential requirement for a candidate material to significantly improve the speed of bone formation on its surface which will allow lowering the implant fixation time and the probability of implant failure is its ability to promote bone matrix maturation and mineralization. A hallmark of osteoblast differentiation both in vivo and in vitro is the formation of an extracellular matrix whose main component is calcium. Therefore, mineralization of osteogenic cultures is considered a functional in vitro endpoint reflecting advanced cell differentiation [33]. In this work, for evaluating in vitro osteogenic differentiation of cultured cells on Ti-23Nb-0.7Ta-2Zr- $0.5 \mathrm{~N}$ and Ti-6Al-4V substrates, qualitative staining and quantitative measurements have been used. Thus, extracellular matrix mineralization was quantified by Alizarin red staining at different time points and results are shown in Fig. 7. Cells seeded on both surfaces and maintained in growth culture medium failed to produce a mineralized matrix even after six weeks of culture. However, after induction in osteogenic medium it can be observed that our developed Ti-23Nb-0.7Ta-2Zr$0.5 \mathrm{~N}$ alloy promoted extracellular matrix secretion and mineralization at cell-material interface to a higher extent than Ti-6Al-4V alloy. At six weeks of culture in osteogenic conditions, the percent of Alizarin red S labeling area for Ti-23Nb-0.7Ta-2Zr- $0.5 \mathrm{~N}$ substrate was significantly larger than that for Ti-6Al-4V control. According to the quantitative results, matrix mineralization on $\mathrm{Ti}-6 \mathrm{Al}-4 \mathrm{~V}$ represented about $42 \%$ of that on $\mathrm{Ti}-23 \mathrm{Nb}-0.7 \mathrm{Ta}-2 \mathrm{Zr}-$ $0.5 \mathrm{~N}$. A possible explanation for this observation is that ions released from biomaterials with 
different chemical composition exert a significant differential effect on osteoblasts behavior. Thus, Thompson and Puleo [34] found that Ti-6Al-4V solutions strongly inhibit osteocalcin synthesis and reduce calcium levels. They concluded that ions associated with Ti-6Al-4V alloy inhibit the normal differentiation of bone marrow stromal cells to mature osteoblasts in vitro, and in vivo may contribute to implant failure by impairing normal bone deposition. More recently, Obata and Takahashi [35] demonstrated that cells cultured in the medium containing $3 \times 10^{-7} \mathrm{M}$ niobium ions display higher alkaline phosphatase (ALP) activity in comparison with normal medium, regardless of the presence of osteogenic factors (ascorbic acid, $\beta$-glycerophosphate and dexamethasone) in the media. Moreover, calcium deposition by the cells cultured in the medium containing $3 \times 10^{-7} \mathrm{M}$ niobium ions was found to be twice as high as those cultured in medium containing no niobium ions. Also, previous studies of osteoblast behavior on $\mathrm{Nb}$ containing alloys indicated a very good in vitro cell response. For instance, Ti-6Al-7Nb was reported to support a more rapid maturation of osteoblasts compared to Ti-6Al-4V [36]. Subsequently, Guo et al. [37] investigated the bone tissue compatibility of a new Ti-35Nb-2Ta-3Zr alloy with a low Young's modulus. The in vitro analysis demonstrated increased cell proliferation, alkaline phosphatase activity, calcium deposition and mRNA expression of osteogenic genes (i.e., ALP, osteocalcin, osteopontin) on Ti-35Nb-2Ta-3Zr alloy compared to Ti-6Al-4V alloy. Only several in vivo studies have described the bone tissue compatibility of implants with low Young's moduli. Thus, Guo et al. [38] studied the bone healing and stability of intramedullary nails made of $\mathrm{Ti}-24 \mathrm{Nb}-4 \mathrm{Zr}-$ 7.9Sn alloy implanted in New Zealand white rabbits. It was found that the low modulus of $\mathrm{Ti}-24 \mathrm{Nb}-4 \mathrm{Zr}-7.9 \mathrm{Sn}$ alloy leads to significant improvement in new bone formation in fractured rabbit tibiae as compared with the control group made of Ti-6Al-4V. Their findings suggest that, in the early days of fixation, nails made of low modulus $\mathrm{Ti}-24 \mathrm{Nb}-4 \mathrm{Zr}-$ 7.9Sn improved new bone formation in the marrow cavity. Shi et al. [39] used the 
osteoporotic rabbit model induced by the combination of ovariectomy and glucocorticoid treatment to determine if the $\mathrm{Ti}-24 \mathrm{Nb}-4 \mathrm{Zr}-7.9 \mathrm{Sn}$ implant with low elastic modulus and high strength can relieve the stress shielding phenomenon and improve the implant survival time. Implants made of $\mathrm{Ti}-24 \mathrm{Nb}-4 \mathrm{Zr}-7.9 \mathrm{Sn}$ were found to possess better stability and boneimplant interface than the TiAlV implants. Histological observations indicated direct bone-to implant contact with no fibrous tissue in the $\mathrm{Ti}-24 \mathrm{Nb}-4 \mathrm{Zr}-7.9 \mathrm{Sn}$ group at 12 weeks, proving that osseointegration were achieved.

Our findings appear in line with the available literature in vitro data revealing that Ti$23 \mathrm{Nb}-0.7 \mathrm{Ta}-2 \mathrm{Zr}-0.5 \mathrm{~N}$ material exhibited good cell adhesion, spreading, proliferation, and enhanced matrix mineralization. Taking into consideration that our material showed 2.42 fold higher mineralization levels than Ti-6Al-4V, it might be a better option for orthopedic applications.

\subsection{Inflammatory response}

Implantation of a biomaterial immediately triggers an inflammatory response orchestrated by macrophages [40]. It is well known that substrate-adherent macrophages become activated in an attempt to phagocytose the biomaterial and that the subsequent cytokine secretion directs the inflammatory and wound healing responses to the biomaterial presence. Previous studies have revealed the important role of cytokines and chemokines in bone healing, through the influence exerted on the recruitment and differentiation of mesenchymal stem cells [41], and the migration and differentiation of osteoclasts $[42,43]$. In general, a proinflammatory cytokine profile is associated with both delayed bone healing and bone loss [44]. While it is subject of controversy whether implant surfaces should sustain macrophage adhesion, promote or inhibit macrophage responses, it is widely accepted that excessive 
macrophage activation correlated with a pro-inflammatory cytokine profile affects implant bioperformance [45].

In the present work gene and protein analysis of the inflammatory cytokines and chemokines TNF- $\alpha$, IL-6, MCP-1 and RANTES was performed by qPCR and ELISA, respectively, and used as a measure of inflammatory response. Results demonstrated differential cytokine gene expression on Ti-23Nb-0.7Ta-2Zr- $0.5 \mathrm{~N}$ and Ti-6Al-4V materials (Fig. 8a). In standard culture conditions, significant lower cytokine mRNA expression levels were noticed following $24 \mathrm{~h}$ of cell exposure to $\mathrm{Ti}-23 \mathrm{Nb}-0.7 \mathrm{Ta}-2 \mathrm{Zr}-0.5 \mathrm{~N}$ when compared to Ti-6Al-4V for TNF- $\alpha$ and RANTES. Furthermore, addition of LPS showed a marked increase in pro-inflammatory cytokines expression by macrophages attached to Ti alloys. In pro-inflammatory conditions we found markedly enhanced expression of IL-6 and RANTES by Ti-6Al-4V when compared to Ti-23Nb-0.7Ta-2Zr-0.5N. However, after $48 \mathrm{~h}$ of culture, the expression of analyzed inflammatory markers was reduced and comparable in both samples suggesting the absence of a persistent inflammatory response. As regards to cytokine production, relatively low levels of cytokines were secreted by macrophages cultured on both surfaces in absence of exogenous stimuli. Conversely, cytokine release was strongly upregulated by the addition of LPS. Despite the remarked differences in cytokine gene expression, no significant changes at the level of cytokine release have been found between the analyzed samples (Fig. 8b). Considering that protein levels are the product of gene expression which has occurred 4-18 h earlier, direct correlation between the ELISA data and the gene expression results at any particular point in time is not necessarily expected.

Taken together, our findings suggest that the material induced a wound healing response, rather than a profound inflammatory response, showing promise for future biomedical applications. 


\section{Conclusions}

The present study addressed the potential of the new $\beta$-type Ti-23Nb-0.7Ta-2Zr- $0.5 \mathrm{~N}$ alloy for future use in bone implant applications. Whereas the material was shown to support MC3T3-E1 pre-osteoblasts attachment, spreading and proliferation to a similar level with that displayed by Ti-6Al-4V control samples, a substantial increase in the differentiation and mineralization ability of osteoblasts was observed for Ti-23Nb-0.7Ta- $2 \mathrm{Zr}-0.5 \mathrm{~N}$ substrate. In addition, no significant inflammatory response was elicited in macrophage cells cultured on this material. The findings of our short term study demonstrate an excellent in vitro biocompatibility, which is critical for the long term success of an osseointegrated implant, and suggest that this material holds promise to enhance bone formation and reduce osseointegration time. However, the clinical relevance of the observation concerning an initially better cell behavior on $\mathrm{Ti}-23 \mathrm{Nb}-0.7 \mathrm{Ta}-2 \mathrm{Zr}-0.5 \mathrm{~N}$ substrate alloy and its biomechanical implications still have to be demonstrated by long-term in vivo studies. 


\section{Acknowledgements}

This work was supported by UEFISCDI through project PNII-ID-PCE 188/2011: “In vitro effects of $\beta$ titanium alloys on the behavior of macrophages and their interactions with osteoblasts". Authors are thankful to Dr. Simona Popescu (Faculty of Applied Chemistry and Materials Science, University Politehnica of Bucharest) for kind help in measuring the water contact angle. 


\section{References}

[1] M. Geetha, A.K. Singh, R. Asokamani, A.K. Gogia, Ti based biomaterials, the ultimate choice for orthopaedic implants - A review, Prog. Mater. Sci. 54 (2009) 397-425.

[2] M. Niinomi, M. Nakai, Titanium-Based Biomaterials for Preventing Stress Shielding between Implant Devices and Bone, Int. J. Biomater. 2011 (2011) Article ID 836587.

[3] D. Raabe, B. Sander, M. Friak, D. Ma, J. Neugebauer, Theory-guided bottom-up design of beta-titanium alloys as biomaterials based on first principles calculations: theory and experiments, Acta Mater. 55 (2007) 4475-4487.

[4] N. Sumitomo, K. Noritake, T. Hattori, K. Morikawa, S. Niwa, K. Sato, M. Niinomi, Experiment study on fracture fixation with low rigidity titanium alloy: plate fixation of tibia fracture model in rabbit, J. Mater. Sci. Mater. Med. 19 (2008) 1581-1586.

[5] M. Niinomi, Trend and present state of titanium alloys with body centered structure for biomedical applications, Bulletin of The Iron and Steel Institute of Japan 15 (2010) 661-670. [6] M. Niinomi, T. Hattori, Effect of Young's modulus in metallic implants on atrophy and bone remodeling, in: T. Sasano, O. Suzuki (Eds.), Interface Oral Health Science, Springer, 2010, pp. 90-99.

[7] C.M. Linter, Neuropsychiatric aspects of trace elements, Br. J. Hosp. Med. 34 (1985) 361365.

[8] M.A. Khan, R.L. Williams, D.F. Williams, The corrosion behaviour of Ti-6Al-4V, Ti$6 \mathrm{Al}-7 \mathrm{Nb}$ and $\mathrm{Ti}-13 \mathrm{Nb}-13 \mathrm{Zr}$ in protein solutions, Biomaterials 20 (1999) 631-637.

[9] D. Kuroda, M. Niinomi, M. Morinaga, Y. Kato, T. Yashiro, Design and mechanical properties of new beta type titanium alloys for implants materials, Mater. Sci. Eng. A 243 (1998) 244-249. 
[10] M. Ikeda, S.Y. Komatsu, I. Sowa, M. Niimoni, Aging behavior of the Ti-29Nb-13Ta4.6Zr new beta alloy for medical implants, Metall. Mater. Trans. 33A (2002) 487-493.

[11] M. Niinomi, T. Hattori, K. Morikawa, T. Kasuga, A. Suzuki, H. Fukui, S. Niwa, Development of low rigidity $\beta$-type titanium alloy for biomedical applications, Mater. Trans. 43 (2002) 2970-2977.

[12] D.M. Gordin, T. Gloriant, G. Nemtoi, R. Chelariu, N. Aelenei, A. Guillou, D. Ansel, Synthesis, structure and electrochemical behavior of a beta $\mathrm{Ti}-12 \mathrm{Mo}-5 \mathrm{Ta}$ alloy as new biomaterial, Mater. Lett. 59 (2005) 2936-2941.

[13] J. Qazi, H.J. Rack, Metastable beta titanium alloys for orthopedic applications, Adv. Eng. Mater. 7 (2005) 993-998.

[14] R. Banerjee, S. Nag, H.L. Fraser, A novel combinatorial approach to the development of beta titanium alloys for orthopaedic implants, Mater. Sci. Eng. C 25 (2005) 282-289.

[15] S. Nag, R. Banerjee, H.L. Fraser, Microstructural evolution and strengthening mechanisms in Ti-Nb-Zr-Ta, Ti-Mo-Zr-Fe and Ti-15Mo biocompatible alloys, Mater. Sci. Eng. C 25 (2005) 357-362.

[16] L.M. Elias, S.G. Schneider, S. Schneider, H.M. Silva, F. Malvisi, Microstructural and mechanical characterization of biomedical $\mathrm{Ti}-\mathrm{Nb}-\mathrm{Zr}-(-\mathrm{Ta})$ alloys, Mater. Sci. Eng. A 432 (2006) 108-112.

[17] T. Gloriant, G. Texier, F. Prima, D. Laillé, D.M. Gordin, I. Thibon, D. Ansel, Synthesis and phase transformations of beta metastable Ti-based alloys containing biocompatible Ta, Mo and Fe betastabilizer elements, Adv. Eng. Mater. 8 (2006) 961-965.

[18] M. Niinomi, Mechanical biocompatibilities of titanium alloys for biomedical applications, J. Mech. Behav. Biomed. Mater. 1 (2008) 30-42. 
[19] Cimpean, V. Mitran, C.M. Ciofrangeanu, B. Galateanu, E. Bertrand, D.M. Gordin, D. Iordachescu, T. Gloriant, Osteoblast cell behavior on the new beta-type Ti25Ta25Nb alloy, Mater. Sci. Eng. C 32 (2012) 1554-1563.

[20] H.Y. Kim, Y. Ikehara, J.I. Kim, H. Hosoda, S. Miyazaki, Martensitic transformation, shape memory effect and superelasticity of Ti-Nb binary alloys, Acta Mater. 54 (2006) 24192429.

[21] S. Miyazaki, H.Y. Kim, H. Hosoda, Development and characterization of Ni-free Tibase shape memory and superelastic alloys, Mater. Sci. Eng. A 438-440 (2006) 18-24.

[22] E. Bertrand, P. Castany, T. Gloriant, Investigation of the martensitic transformation and the damping behavior of a superelastic Ti-Ta-Nb alloy, Acta Mater. 61 (2013) 511-518.

[23] X. Liu, S. Wu, K.W.K. Yeung, Y.L. Chan, T. Hub, Z. Xu, X. Liu, J.C.Y. Chung, K.M.C. Cheung, P.K. Chu, Relationship between osseointegration and superelastic biomechanics in porous NiTi scaffolds, Biomaterials 32 (2011) 330-338.

[24] L.G. Griffith, G. Naughton, Tissue Engineering-Current Challenges and Expanding Opportunities, Science 295 (2002) 1009-1014.

[25] ASTM D7334 - 08, Standard Practice for Surface Wettability of Coatings, Substrates and Pigments by Advancing Contact Angle Measurement, ASTM International, 2008.

[26] L. Bacakova, E. Filova, M. Parizek, T. Ruml, V. Svorcik, Modulation of cell adhesion, proliferation and differentiation on materials designed for body implants, Biotechnol. Adv. 29 (2011) 739-767.

[27] P. Roach, D. Eglin, K. Rohde, C.C. Perry, Modern biomaterials: a review - bulk properties and implications of surface modifications, J. Mater. Sci. Mater. Med. 18 (2007) $1263-1277$. 
[28] G. Brunton, I.R. MacPherson, M.C. Frame, Cell adhesion receptors, tyrosine kinases and actin modulators: a complex three-way circuitry, Biochim. Biophys. Acta 1692 (2004) 121144.

[29] C.S. Chen, J. Tan, J. Tien, Mechanotransduction at cell-matrix and cell-cell contacts, Annu. Rev. Biomed. Eng. 6 (2004) 275-302.

[30] M. Bigerelle, K. Anselme, Bootstrap analysis of the relation between initial adhesive events and long-term cellular functions of human osteoblasts cultured on biocompatible metallic substrates, Acta Biomater. 1 (2005) 499-510.

[31] J.D. Humphries, P. Wang, C. Streuli, B. Geiger, M.J. Humphries, C. Ballestrem, Vinculin controls focal adhesion formation by direct interactions with talin and actin, J. Cell Biol. 179 (2007) 1043-1057.

[32] M. Arciniegas, J.M. Manero, E. Espinar, J.M. Llamas, J.M. Barrera, F.J. Gil, New Nifree superelastic alloy for orthodontic applications, Mater. Sci. Eng. C 33 (2013) 3325-3328. [33] C.D. Hoemann, H. El-Gabalawy, M.D. McKee, In vitro osteogenesis assays: Influence of the primary cell source on alkaline phosphatase activity and mineralization, Pathol. Biol. 57 (2009) 318-323.

[34] G.J. Thompson, D.A. Puleo, Ti-6Al-4V ion solution inhibition of osteogenic cell phenotype as a function of differentiation time course in vitro, Biomaterials 17 (1996) 19491954.

[35] A. Obata, Y. Takahashi, T. Miyajima, K. Ueda, T. Narushima, T. Kasuga, Effects of niobium ions released from calcium phosphate invert glasses containing $\mathrm{Nb} 2 \mathrm{O} 5$ on osteoblast-like cell functions, ACS Appl. Mater. Interfaces 4 (2012) 5684-5690.

[36] L. Shapira, A. Klinger, A. Tadir, A. Wilensky, A. Halabi, Effect of a niobium-containing titanium alloy on osteoblast behavior in culture, Clin. Oral Implants Res. 20 (2009) 578-582. 
[37] Y. Guo, D. Chen, M. Cheng, W. Lu, L. Wang, X. Zhang, The bone tissue compatibility of a new Ti35Nb2Ta3Zr alloy with a low Young's modulus, Int. J. Mol. Med. 31 (2013) 689697.

[38] Z. Guo, J. Fu, Y. Zhang, Y. Hu, Z. Wu, L. Shi, M. Sha, S. Li, Y. Hao, R. Yang, Early effect of $\mathrm{Ti}-24 \mathrm{Nb}-4 \mathrm{Zr}-7.9 \mathrm{Sn}$ intramedullary nails on fractured bone, Mater. Sci. Eng. C 29 (2009) 963-968.

[39] L. Shi, L. Wang, Y. Duan, W. Lei, Z. Wang, J. Li, X. Fan, X. Li, S. Li, Z. Guo, The Improved Biological Performance of a Novel Low Elastic Modulus Implant, PLoS ONE 8(2) (2013) e55015, doi:10.1371/journal.pone.0055015.

[40] J.M. Anderson, A. Rodriguez, D.T. Chang, Foreign body reaction to biomaterials, Semin. Immunol. 20 (2008) 86-100.

[41] H. Ito, Chemokines in mesenchymal stem cell therapy for bone repair: a novel concept of recruiting mesenchymal stem cells and the possible cell sources, Mod. Rheumatol. 21 (2011) 113-121.

[42] L. Kindle, L. Rothe, M. Kriss, P. Osdoby, P. Collin-Osdoby, Human microvascular endothelial cell activation by IL-1 and TNF-alpha stimulates the adhesion and transendothelial migration of circulating human CD14+ monocytes that develop with RANKL into functional osteoclasts, J. Bone Miner. Res. 21 (2006) 193-206.

[43] K. Nakahama, Cellular communications in bone homeostasis and repair, Cell. Mol. Life Sci. 67 (2010) 4001-4009.

[44] S.B. Goodman, T. Ma, Cellular chemotaxis induced by wear particles from joint replacements, Biomaterials 31 (2010) 5045-5050.

[45] S.B. Goodman, Wear particles, periprosthetic osteolysis and the immune system, Biomaterials 28 (2007) 5044-5048. 


\section{Figure caption}

Fig. 1. Optical micrograph of the Ti-23Nb-0.7Ta-2Zr-0.5N alloy.

Fig. 2. The XPS Survey / wide band spectrum of the Ti-23Nb-0.7Ta-2Zr-0.5N alloy.

Fig. 3. Stress-strain tensile curves until rupture and after loading/unloading cycles between 0 and $4 \%$ of strain (center part) form the Ti-23Nb-0.7Ta-2Zr- $0.5 \mathrm{~N}$ alloy.

Fig. 4. AFM maps from Ti-23Nb-0.7Ta-2Zr-0.5N (a) and Ti-6Al-4V (b).

Fig. 5. Fluorescent microscopy images of MC3T3-E1 cells cultured for $3 \mathrm{~h}$ and $24 \mathrm{~h}$ on Ti$23 \mathrm{Nb}-0.7 \mathrm{Ta}-2 \mathrm{Zr}-0.5 \mathrm{~N}$ and Ti-6Al-4V surfaces. Actin microfilaments and vinculin adhesion plaques were stained red and green, respectively. Cells exhibited well-defined cytoskeletal organization on both samples.

Fig. 6. MTT assay, formazan absorbance as a measure of cell proliferation from MC3T3-E1 cells cultured on $\mathrm{Ti}-23 \mathrm{Nb}-0.7 \mathrm{Ta}-2 \mathrm{Zr}-0.5 \mathrm{~N}$ and $\mathrm{Ti}-6 \mathrm{Al}-4 \mathrm{~V}$ surfaces for different times of culture. Results are presented as means $\pm \operatorname{SD}(n=3)$.

Fig. 7. Digital images of the analyzed samples showing extracellular matrix mineralization (upper panel) and colorimetrically quantitative analysis (lower panel) after 2, 4 and 6 weeks of incubation. $\cdots \cdot p<0.001$ compared with the Ti-6Al-4V samples maintained in osteogenic induction medium.

Fig. 8. A) Cytokine gene expression displayed by RAW 264.7 cells cultured onto Ti-23Nb$0.7 \mathrm{Ta}-2 \mathrm{Zr}-0.5 \mathrm{~N}$ and Ti-6Al-4V surfaces. B) Mean $( \pm \mathrm{SD})$ levels of cytokines secreted into culture media after $24 \mathrm{~h}$ and $48 \mathrm{~h}$ culture of RAW 264.7 macrophages on test samples, as detected by ELISA. $\bullet p<0.05, \cdots p<0.001$ vs. Ti-6Al-4V; $\cdots p<0.001$ vs. Ti-6Al-4V + LPS. 


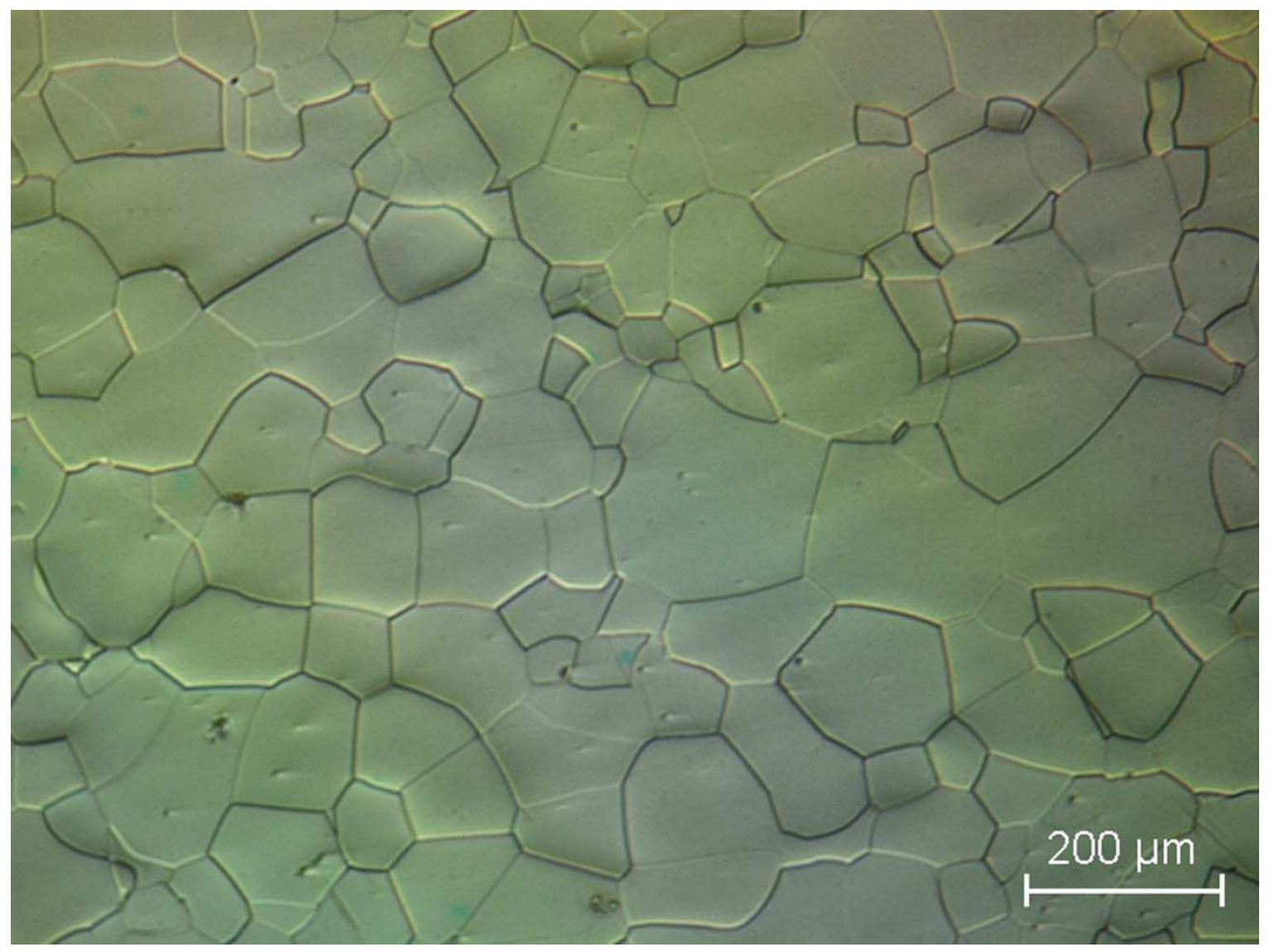

Fig 1

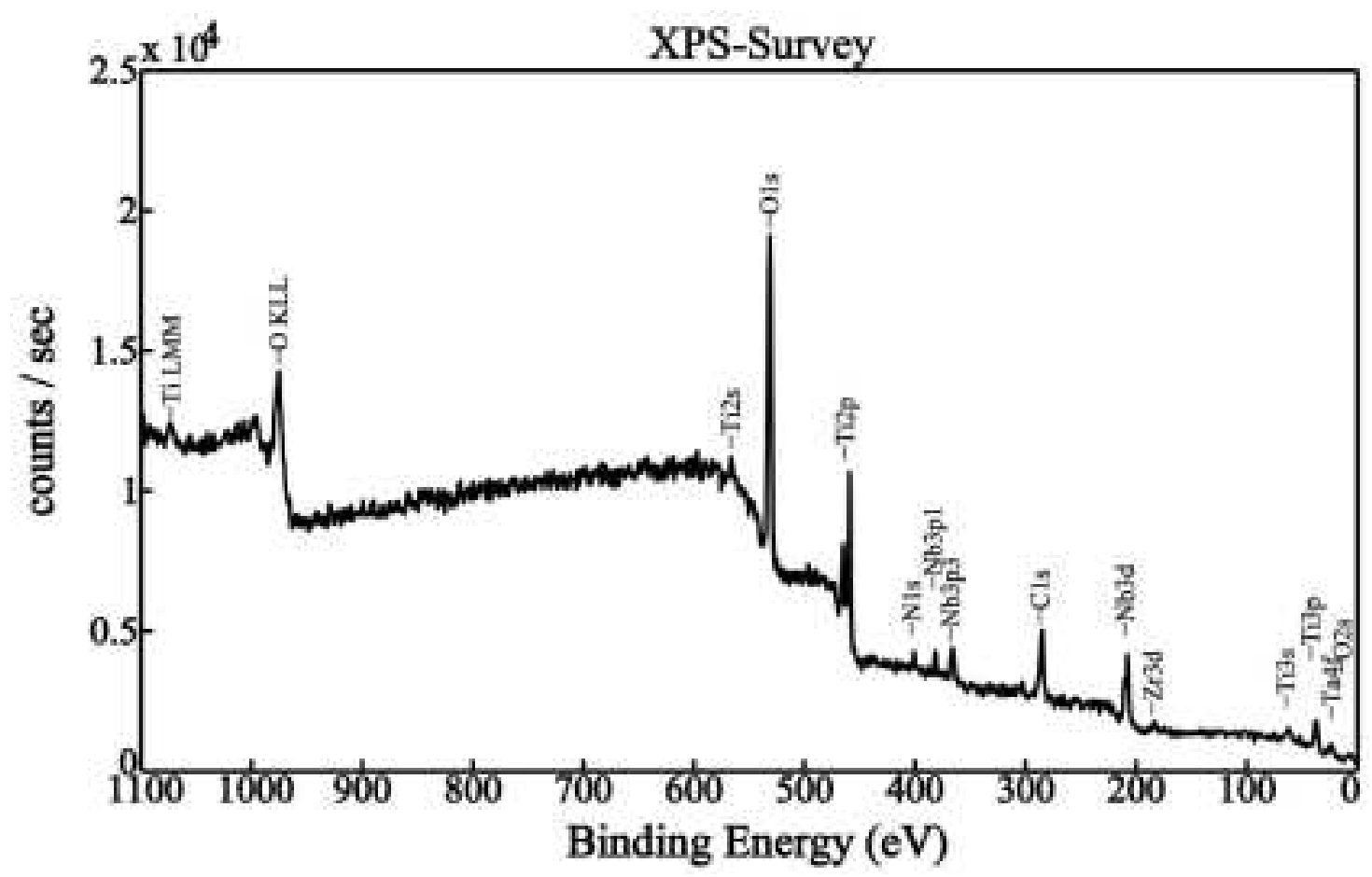

Fig 2 


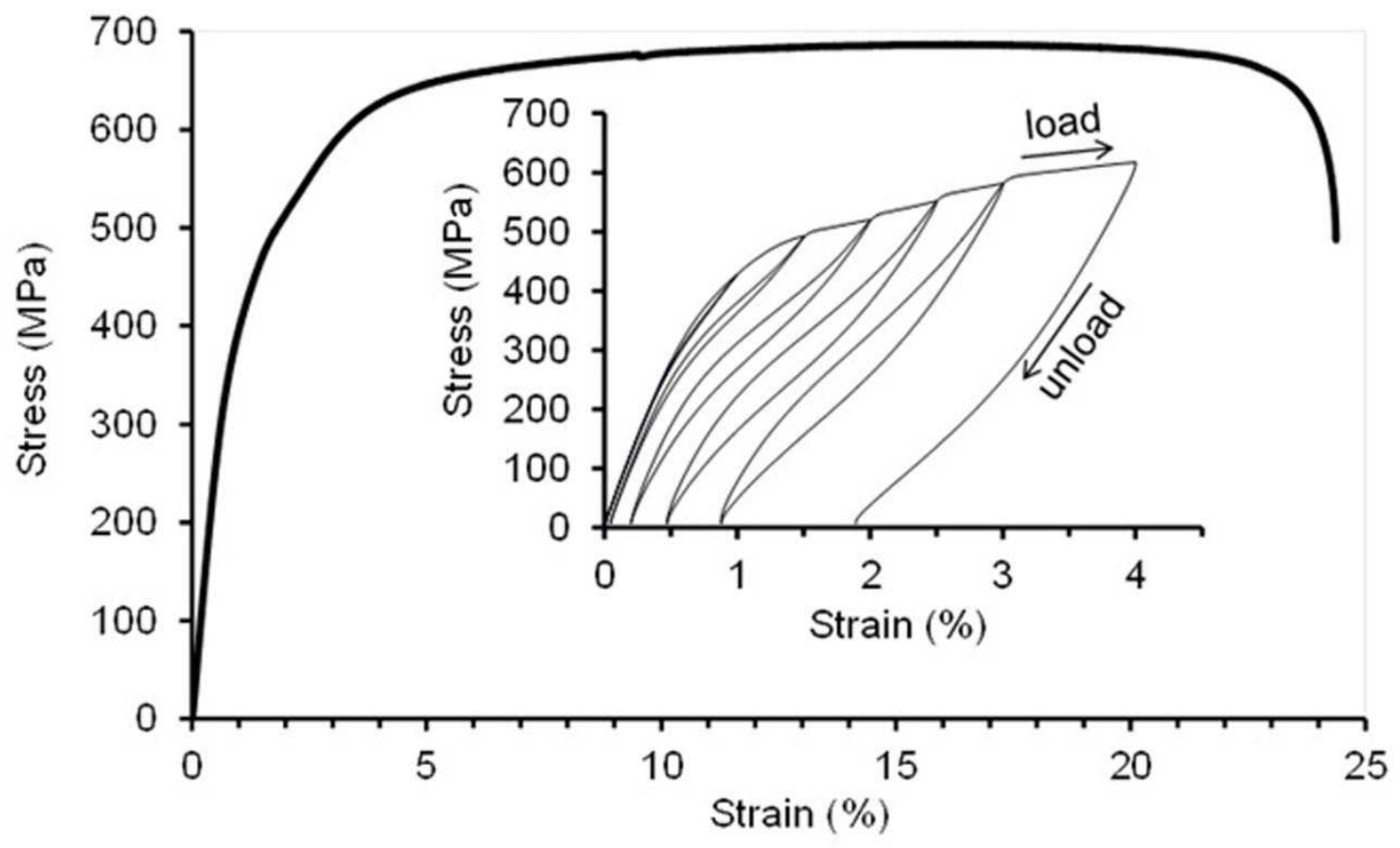

Fig 3
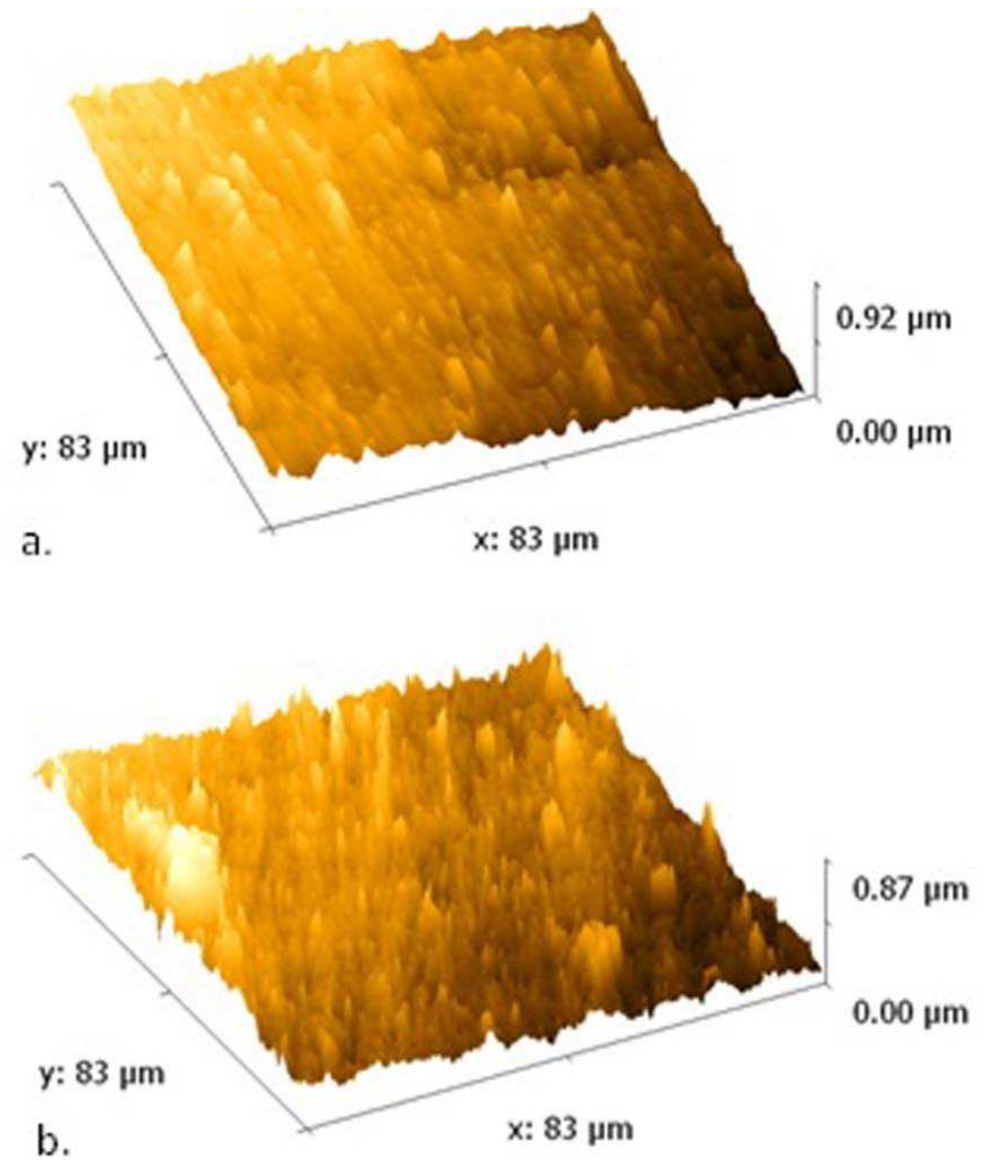

Fig 4 


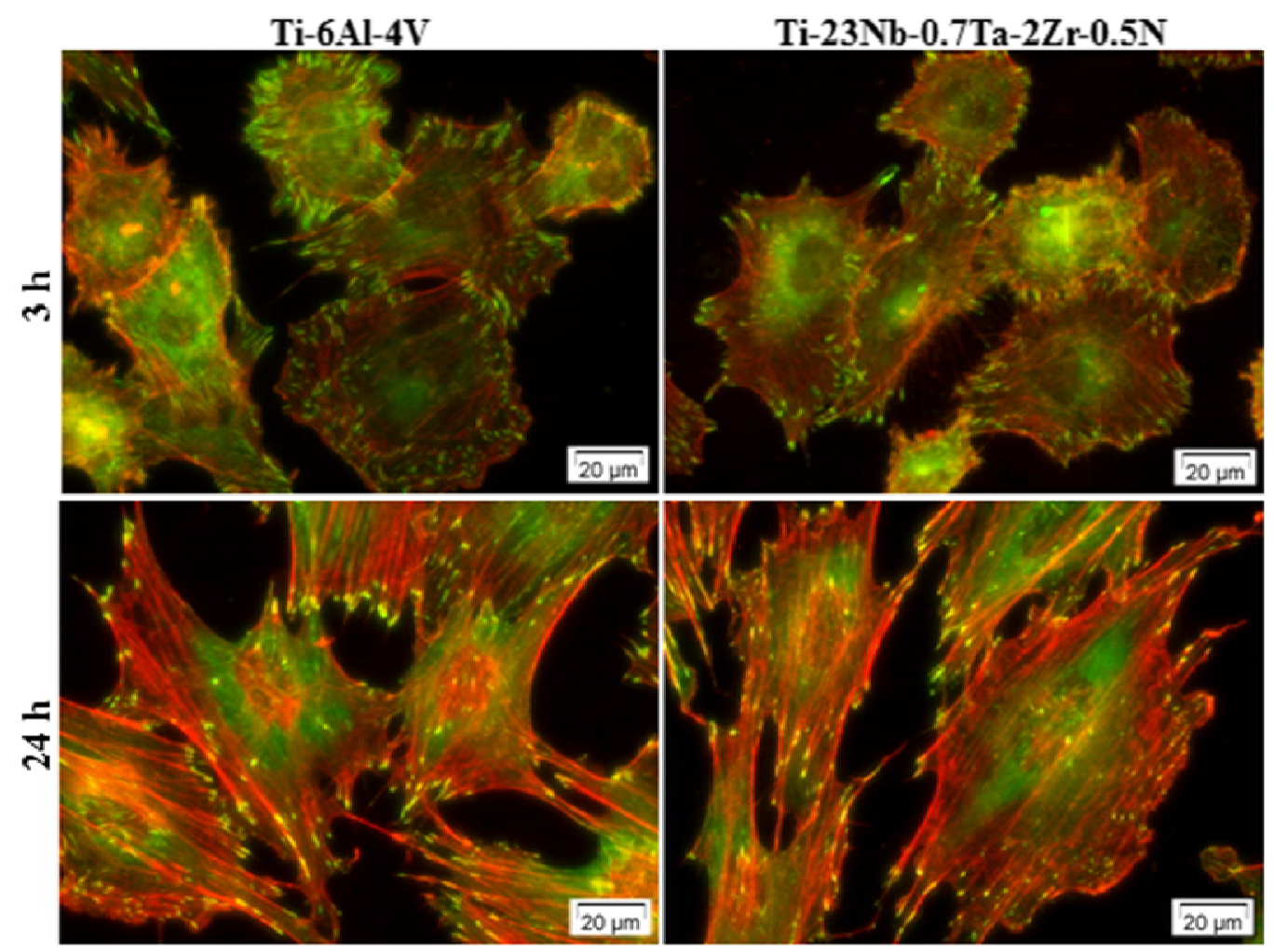

Fig 5

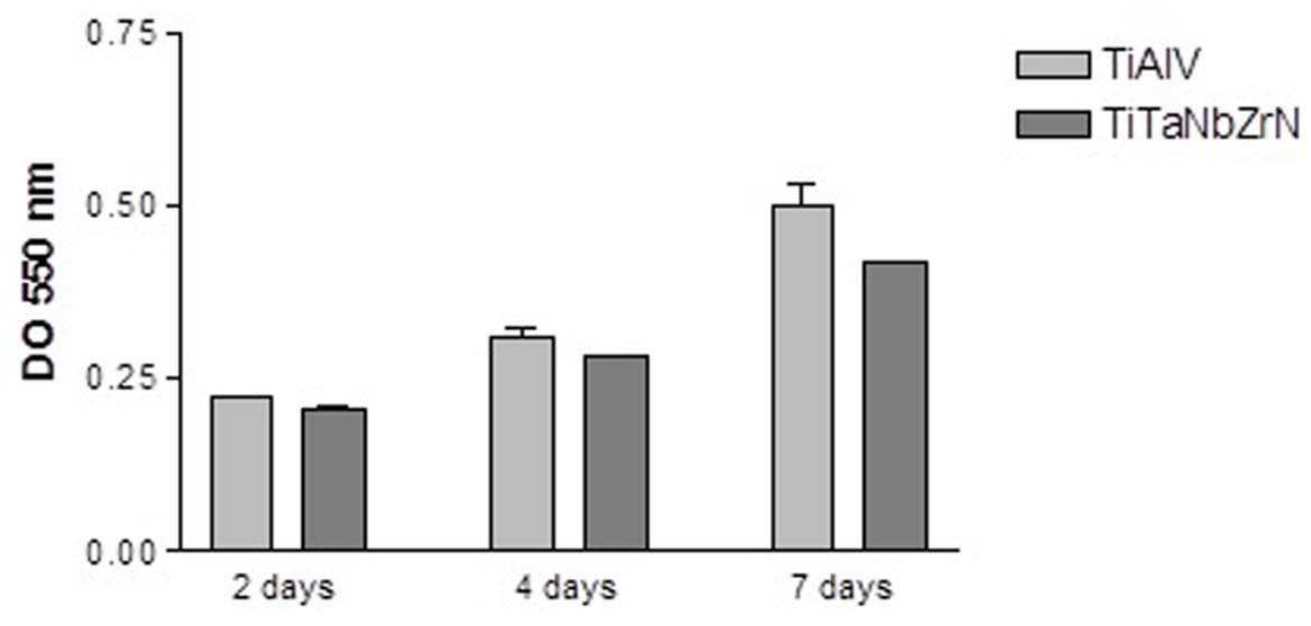

Fig 6 


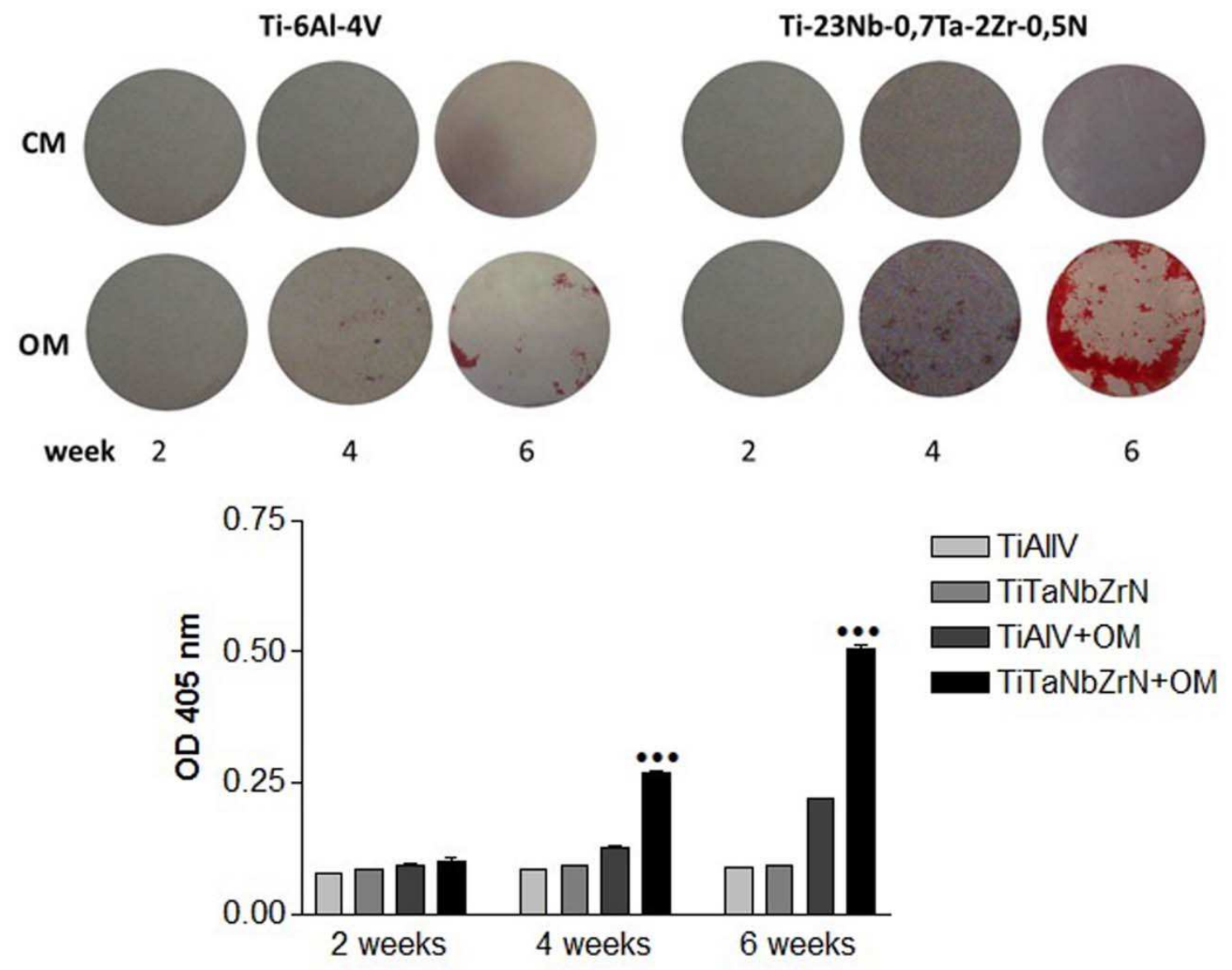

Fig 7 

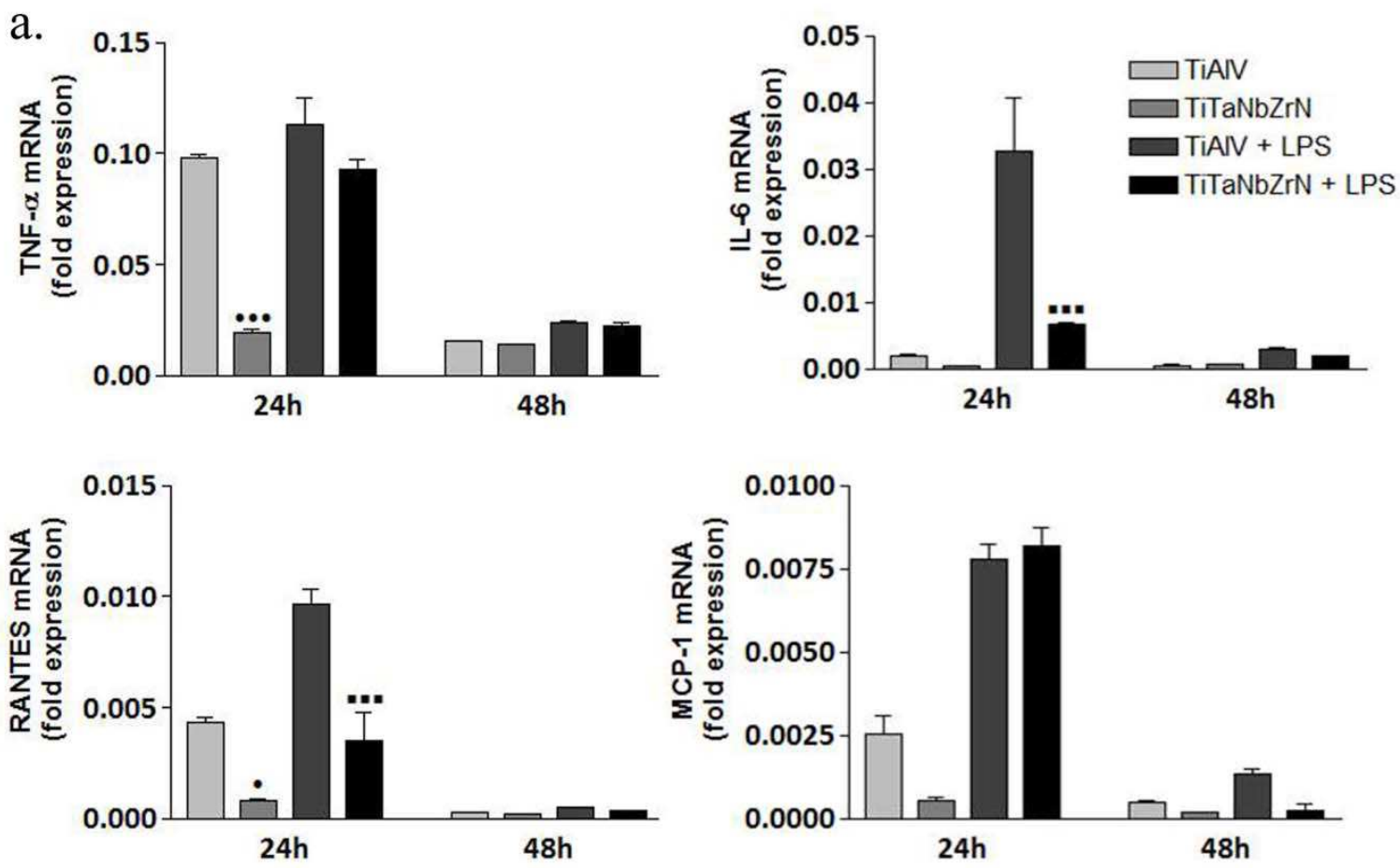

b.
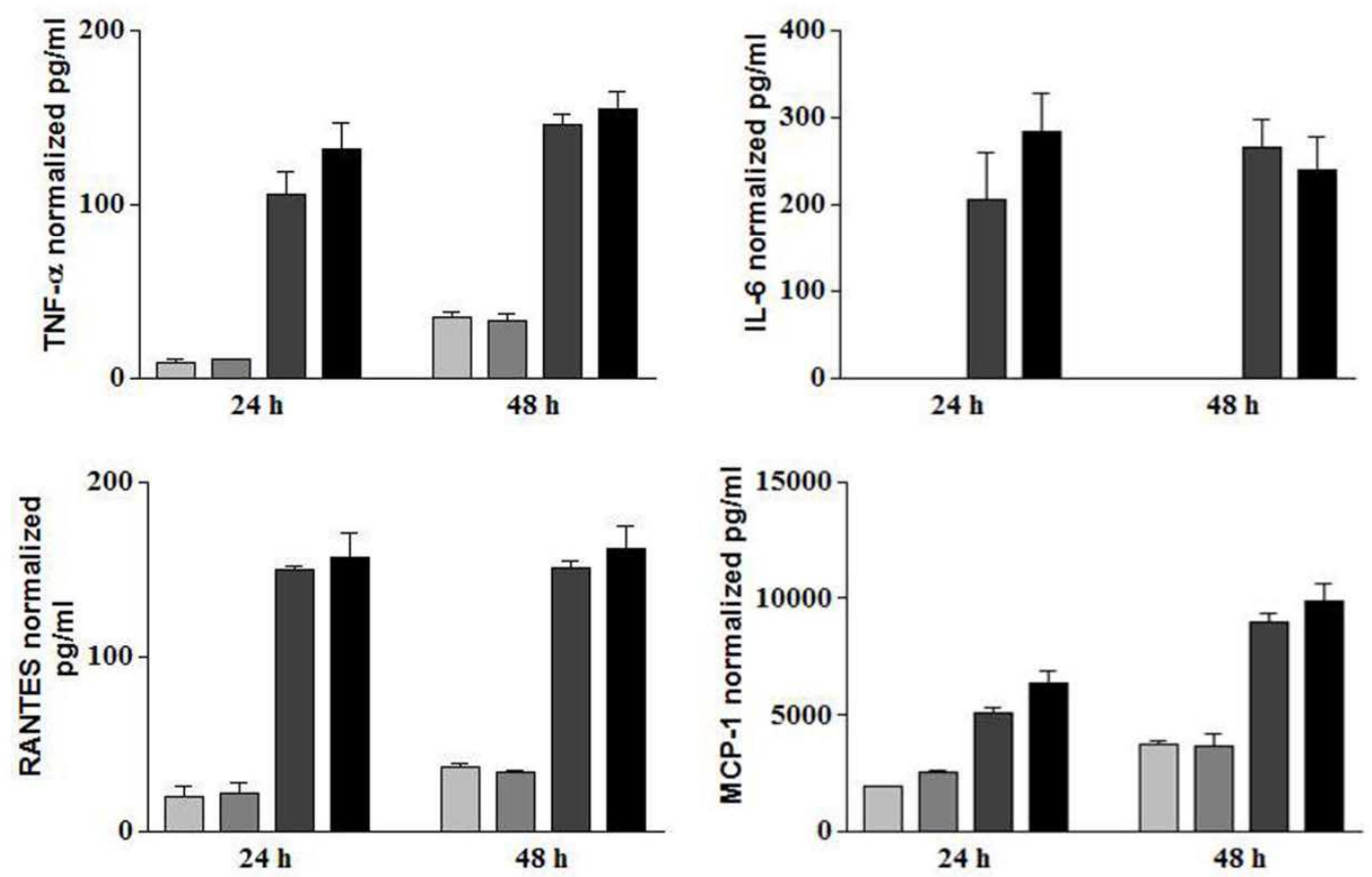

Fig 8 